ARTICLE

Received 16 Aug 2016 | Accepted 15 Dec 2016 | Published 6 Feb 2017

DOI: $10.1038 /$ ncomms14308

OPEN

\title{
Proton enhanced dynamic battery chemistry for aprotic lithium-oxygen batteries
}

Yun Guang Zhu', Qi Liu ${ }^{2}$, Yangchun Rong ${ }^{2}$, Haomin Chen ${ }^{1}$, Jing Yang ${ }^{1}$, Chuankun Jia ${ }^{1}$, Li-Juan Yu ${ }^{3}$, Amir Karton $^{3}$, Yang Ren ${ }^{2}$, Xiaoxiong $\mathrm{Xu}^{4}$, Stefan Adams $^{1} \&$ Qing Wang ${ }^{1}$

Water contamination is generally considered to be detrimental to the performance of aprotic lithium-air batteries, whereas this view is challenged by recent contrasting observations. This has provoked a range of discussions on the role of water and its impact on batteries. In this work, a distinct battery chemistry that prevails in water-contaminated aprotic lithium-oxygen batteries is revealed. Both lithium ions and protons are found to be involved in the oxygen reduction and evolution reactions, and lithium hydroperoxide and lithium hydroxide are identified as predominant discharge products. The crystallographic and spectroscopic characteristics of lithium hydroperoxide monohydrate are scrutinized both experimentally and theoretically. Intriguingly, the reaction of lithium hydroperoxide with triiodide exhibits a faster kinetics, which enables a considerably lower overpotential during the charging process. The battery chemistry unveiled in this mechanistic study could provide important insights into the understanding of nominally aprotic lithium-oxygen batteries and help to tackle the critical issues confronted.

\footnotetext{
${ }^{1}$ Department of Materials Science and Engineering, Faculty of Engineering, National University of Singapore, 117576 Singapore, Singapore. ${ }^{2} X$-Ray Science Division, Advanced Photon Source, Argonne National Laboratory, Argonne, Illinois 60439, USA. ${ }^{3}$ School of Chemistry and Biochemistry, The University of Western Australia, 35 Stirling Highway Crawley, Perth, Western Australia 6009, Australia. ${ }^{4}$ Ningbo Institute of Material Technology and Engineering, Chinese Academy of Sciences, Ningbo 315201, China. Correspondence and requests for materials should be addressed to Q.W. (email: msewq@nus.edu.sg).
} 
T he pursuit of high-energy power sources going beyond the state-of-the-art Li-ion batteries has evoked a surge of intensive studies of the lithium-air battery, as it has the potential of achieving nearly the same level of energy density as that of gasoline ${ }^{1}$. Although profound studies have been carried out, several technical challenges severely hinder the development of lithium-air batteries for practical application. Taking the most studied aprotic lithium-oxygen $\left(\mathrm{Li}-\mathrm{O}_{2}\right)$ system as an example, the formation of insoluble and insulating lithium peroxide $\left(\mathrm{Li}_{2} \mathrm{O}_{2}\right)$ during the discharge process leads to surface passivation and pore clogging of the cathode, which results in low round-trip energy efficiency and limited capacity ${ }^{2-4}$. Advances in electrocatalysts so far seem to have achieved only limited success in addressing the above issues. It remains a significant challenge that in a Li-air battery the oxygen reduction reaction (ORR) and oxygen evolution reaction (OER) take place electrocatalytically at the 'solid-solid' interface, which is intrinsically less favourable than those at the 'liquid-solid' interface in other metal-air batteries (or fuel cells) ${ }^{5-9}$. As such, soluble redox catalysts have recently been extensively investigated to transform the solid-state electrode reaction into a solution phase reaction ${ }^{10-19}$. Among the soluble OER catalyst, iodide received the most attention owing to its relatively good stability. Another critical issue for the aprotic Li- $\mathrm{O}_{2}$ battery is that it is in essence an open system nominally, for which not only oxygen is fed into the battery upon operation; other species in air such as moisture are also inevitably introduced into the system. The presence of water in the electrolyte is generally considered to be detrimental as it attacks lithium metal at the anode and it may become involved in the ORR reaction at the cathode. For instance, water and protons were found in one study to significantly influence the crystal growth of $\mathrm{Li}_{2} \mathrm{O}_{2}$ (refs 20,21). In other studies, lithium hydroxide (LiOH) was however identified as the main discharge product in the presence of moisture ${ }^{15,16}$, whereas disputes persist on the oxidation of $\mathrm{LiOH}$ by triiodide $\left(\mathrm{I}_{3}^{-}\right)$during charging process $^{22-27}$. Moreover, water was believed to catalyse the ORR reaction in aprotic $\mathrm{Li}-\mathrm{O}_{2}$ battery resulting in the formation of $\mathrm{LiOH}^{28}$, and good cycling performance was achieved in humid $\mathrm{O}_{2}$ (ref. 29). Therefore, owing to the complexity of the reaction, the battery chemistry of water-contaminated aprotic Li- $\mathrm{O}_{2}$ cell remains to be elucidated ${ }^{30}$.

Here we carefully investigate the influence of water on the battery chemistry of aprotic Li- $\mathrm{O}_{2}$ cells when LiI is used as the OER redox catalyst. With the help of a $\mathrm{Li}^{+}$-conducting ceramic membrane, we safely exclude any side-effects that may incur by the reactions of water and redox mediators with the lithium anode. One finding is that along with $\mathrm{LiOH}$, lithium hydroperoxide ( $\mathrm{LiOOH}$ ) is detected to be one of the predominant discharge products, heralding a distinct battery chemistry for water-contaminated $\mathrm{Li}-\mathrm{O}_{2}$ batteries. As a rarely reported lithium compound, we study the crystallographic and spectroscopic characteristics of $\mathrm{LiOOH}$ both experimentally and theoretically, and find $\mathrm{LiOOH}$ presents much faster reaction kinetics towards $\mathrm{I}_{3}^{-}$as compared with $\mathrm{Li}_{2} \mathrm{O}_{2}$ and $\mathrm{LiOH}$. A two-stage charging process is proposed in terms of the detailed studies to elucidate the mechanism of $\mathrm{Li}-\mathrm{O}_{2}$ cells involving water in the battery reactions.

\section{Results}

Identification and characterization of LiOOH. Our study started off from the assessment of the reactivity of various discharge products of $\mathrm{Li}^{-} \mathrm{O}_{2}$ batteries towards oxidation by $\mathrm{I}_{3}^{-}$. Titrations of $\mathrm{Li}_{2} \mathrm{O}_{2}$ and $\mathrm{LiOH}$ with $\mathrm{I}_{3}^{-}$were firstly conducted in dimethoxyethane (DME) solutions. Despite the slightly more positive potential $\mathrm{I}_{3}^{-}$stays intact in $\mathrm{Li}_{2} \mathrm{O}_{2}$ suspension even after stirring for $12 \mathrm{~h}$ (Supplementary Fig. 1), which can be explained by the sluggish reaction between the two species in accordance with our previous computational and experimental observation ${ }^{17}$. A similar phenomenon was observed here for $\mathrm{LiOH}$, suggesting that in vigorously dried aprotic solution $\mathrm{I}_{3}^{-}$cannot be removed by $\mathrm{Li}_{2} \mathrm{O}_{2}$ and $\mathrm{LiOH}$ within the timescale of the titration. After adding $\mathrm{H}_{2} \mathrm{O}$ into the above $\mathrm{Li}_{2} \mathrm{O}_{2}$ suspension, the colour of $\mathrm{I}_{3}^{-}$ was quickly bleached as a result of rapid reduction of $\mathrm{I}_{3}^{-}$. In contrast, the presence of $\mathrm{H}_{2} \mathrm{O}$ in $\mathrm{LiOH}$ solution did not cause an appreciable change, whereas the bleaching happened instantaneously when $\mathrm{H}_{2} \mathrm{O}_{2}$ was added into the $\mathrm{LiOH}$ solution, although $\mathrm{H}_{2} \mathrm{O}_{2}$ itself was found to be stable with $\mathrm{I}_{3}^{-}$ (Supplementary Fig. 1). To understand the above phenomena, we noticed the following two reactions for $\mathrm{Li}_{2} \mathrm{O}_{2}$ and $\mathrm{LiOH}$ have been reported, respectively ${ }^{31,32}$ :

$$
\begin{aligned}
& \mathrm{Li}_{2} \mathrm{O}_{2}+\mathrm{H}_{2} \mathrm{O} \rightarrow \mathrm{LiOOH}+\mathrm{LiOH} \\
& \mathrm{LiOH}+\mathrm{H}_{2} \mathrm{O}_{2} \rightarrow \mathrm{LiOOH}+\mathrm{H}_{2} \mathrm{O}
\end{aligned}
$$

In the presence of surplus water, the solid products of both reactions are expected to be in the hydrated form, $\mathrm{LiOOH} \cdot \mathrm{H}_{2} \mathrm{O}$ and $\mathrm{LiOH} \cdot \mathrm{H}_{2} \mathrm{O}^{33}$. Interestingly, if not coincidentally, both reactions point to the same product- $\mathrm{LiOOH}$, implying that the bleaching of $\mathrm{I}_{3}^{-}$might be induced by this compound. Though its crystal structure is not known, various authors suggest it to be the intermediate when producing $\mathrm{Li}_{2} \mathrm{O}_{2}$ by reactions of $\mathrm{H}_{2} \mathrm{O}_{2}$ with $\mathrm{Li}$ alcoholates in the corresponding alcohol (that is, methanol, ethanol and references therein) ${ }^{34}$.

Hence, on the basis of the above titration tests, the reactivity of $\mathrm{LiOOH}$ is the highest and $\mathrm{LiOH}$ is the lowest towards oxidation by $\mathrm{I}_{3}^{-}$. Whereas the comparison is arguably supported by the titrations, the formation of $\mathrm{LiOOH}$, its reaction with $\mathrm{I}_{3}^{-}$, and more importantly the existence of the compound in $\mathrm{Li}^{-} \mathrm{O}_{2}$ battery, need to be unambiguously characterized and identified.

To discern the characteristics of $\mathrm{LiOOH}$ from $\mathrm{LiOH}$ and $\mathrm{Li}_{2} \mathrm{O}_{2}$, the three compounds were concertedly characterized by synchrotron X-ray diffraction (XRD), Raman and Fourier transform infrared (FTIR) spectroscopy measurements with attenuated total reflection (ATR) mode, for which both $\mathrm{LiOH}$ and $\mathrm{Li}_{2} \mathrm{O}_{2}$ were used as received, whereas wet powder of $\mathrm{LiOOH}$ was prepared by a simple reaction between $\mathrm{LiOH}$ and $\mathrm{H}_{2} \mathrm{O}_{2}$ in water/DME following reaction (2).

The structures of four different $\mathrm{Li}$ compounds were characterized by powder XRD (Supplementary Fig. 2). The diffraction pattern of $\mathrm{LiOOH}$ is clearly discriminated from those of $\mathrm{LiOH}, \mathrm{Li}_{2} \mathrm{O}_{2}$ and $\mathrm{Li}_{2} \mathrm{O}$. In order to figure out the structure of the obtained $\mathrm{LiOOH}$, high-resolution powder XRD was performed at 11-BM, Advanced Photon Source, Argonne National Lab (Fig. 1a). As seen from the LeBail fit results in Supplementary Fig. 3, the diffraction pattern of the $\mathrm{LiOOH}$ phase could be well indexed to a triclinic structure with $P 1$ or $P \overline{1}$ symmetry and lattice parameters: $a=6.3688 \AA, b=6.0878 \AA, c=3.2074 \AA, \alpha=79.598^{\circ}$, $\beta=101.832^{\circ}, \gamma=102.311^{\circ}$, volume $=117.69 \AA^{3}$. The goodness of indexing, $\mathrm{F}(28)$, is as high as 795.1 with a zero-shift as small as $-0.0009^{\circ}$, which together indicates that the fitting result is highly reliable. LeBail fits of an additional high-resolution XRD pattern for the $2 \theta$ range up to $22^{\circ}$ ( $2 \theta$ angle) showed result very close to those derived from the lower $2 \theta$ angle range.

The crystal structure of $\mathrm{LiOOH}$ was solved from powder data starting from a comparison of the atomic arrangements of various compounds with related chemical compositions and reduced cells, noting that the close similarity of lattice parameters $a$ and $b$ as well as of $\beta$ and $\gamma$ suggests that the structure may be seen as a distorted variant of a monoclinic $\mathrm{C} 2 / \mathrm{m}$ or even an orthorhombic body-centred structure as originally proposed for $\mathrm{LiOOH} \cdot \mathrm{H}_{2} \mathrm{O}$ by $\mathrm{Cohen}^{33}$. Rietveld refinements of several of these starting 
models converged to the structure shown in Fig. 2 with profile $\mathrm{R}$ and $\mathrm{Chi}^{2}$ values $\left(\mathrm{R}_{\mathrm{wp}}=7.86 \%, \mathrm{R}_{\mathrm{p}}=6.10 \%, \chi^{2}=2.93\right)$ closely approximating those of the model-free LeBail fit (Supplementary Fig. 3) clarifying that for the available data quality no alternative structure model can yield a significantly closer match. Accordingly, the bond valence sums (when using soft BV parameters $)^{35-37}$ of all atoms in the refined structure are close to the expectation value leading to a low global instability index of $\mathrm{GII}=0.077$ underlying the plausibility of the structure model. Geometry optimization of the result from the Rietveld refinement by DFT confirmed that this structure is metastable. Details of the structure parameters resulting from both the Rietveld refinement and the DFT geometry optimization are given in the supplementary material (Supplementary Tables 1 and 2). The structure consists of chains of $\mathrm{H}$-bridged $\mathrm{OOH}^{-}$ions as well as of $\mathrm{Li}^{+}$ions arranged along the c-direction $(\mathrm{O}-\mathrm{H} \cdots \mathrm{O}$ distances 1.12 and $1.46 \AA$ from Rietveld refinement, or 1.07 and $1.46 \AA$ from the DFT data), where each $\mathrm{Li}^{+}$is tetrahedrally coordinated by $\mathrm{O}$ atoms of two water molecules and two $\mathrm{HOO}^{-}$ anions. The atomic arrangement is closely related to the one reported earlier for monoclinic $\mathrm{LiOH} \cdot \mathrm{H}_{2} \mathrm{O}$ (Space group $\mathrm{C} 2 / \mathrm{m}$ ), as becomes more clearly visible when the primitive cell is used for that structure (see Fig. 2c). The structural similarity of $\mathrm{LiOOH} \cdot \mathrm{H}_{2} \mathrm{O}$ and $\mathrm{LiOH} \cdot \mathrm{H}_{2} \mathrm{O}$ also leads to similar stability. At $0 \mathrm{~K}$ the $\mathrm{LiOOH} \cdot \mathrm{H}_{2} \mathrm{O}$ should according to the DFT calculations be marginally stable against the decomposition into $\mathrm{LiOH} \cdot \mathrm{H}_{2} \mathrm{O}$ and $1 / 2 \mathrm{O}_{2}$, whereas at ambient conditions, the entropically favoured decomposition of $\mathrm{LiOOH} \cdot \mathrm{H}_{2} \mathrm{O}$ proceeds easily. In the presence of $\mathrm{CO}_{2}$ from ambient air $\mathrm{LiOH} \cdot \mathrm{H}_{2} \mathrm{O}$ then reacts further to form $\mathrm{Li}_{2} \mathrm{CO}_{3}$ (Supplementary Figs 4 and 5).

The Raman spectrum shown in Fig. $1 \mathrm{~b}$ for the $\mathrm{LiOOH} \cdot \mathrm{H}_{2} \mathrm{O}$ sample reveals a distinct characteristic peak at around $860 \mathrm{~cm}^{-1}$, assigned to the stretching of $\mathrm{O}-\mathrm{O}$ bond based on the density functional theory (DFT) calculations (Supplementary Figs 6 and 7). In comparison, the $\mathrm{O}-\mathrm{O}$ bond stretching of $\mathrm{Li}_{2} \mathrm{O}_{2}$ and $\mathrm{H}_{2} \mathrm{O}_{2}$ molecules is observed at $\sim 790$ and $877 \mathrm{~cm}^{-1}$ (Supplementary Fig. 8), respectively, just straddling that of $\mathrm{LiOOH} \cdot \mathrm{H}_{2} \mathrm{O}$. Other fingerprint peaks for $\mathrm{LiOOH} \cdot \mathrm{H}_{2} \mathrm{O}$ were also observed at $80-150 \mathrm{~cm}^{-1}$, implying $\mathrm{LiOOH} \cdot \mathrm{H}_{2} \mathrm{O}$ is indeed a different species from $\mathrm{LiOH}$ and $\mathrm{Li}_{2} \mathrm{O}_{2}$. Characteristic IR responses of $\mathrm{LiOOH} \cdot \mathrm{H}_{2} \mathrm{O}$ were also detected in the FTIR measurement (Supplementary Fig. 9), where the peak at $1,643 \mathrm{~cm}^{-1}$ is identified as a $\mathrm{H}_{2} \mathrm{O}$ bending mode. Although other vibrations are not yet specified owing to a lack of reference data, the distinct spectra well evince $\mathrm{LiOOH} \cdot \mathrm{H}_{2} \mathrm{O}$ as a new species relevant to $\mathrm{Li}-\mathrm{O}_{2}$ batteries.
Electrochemical properties of LiOOH. To investigate the catalytic effect of $\mathrm{I}_{3}^{-}$on the oxidation of the above lithium compounds, rotating disk electrode (RDE) was employed to probe the reactions, in which the powders of $\mathrm{LiOOH} \cdot \mathrm{H}_{2} \mathrm{O}, \mathrm{Li}_{2} \mathrm{O}_{2}$ and $\mathrm{LiOH}$ were dispersed in LiI electrolyte. As shown in Fig. 3a, in the presence of $\mathrm{LiOOH} \cdot \mathrm{H}_{2} \mathrm{O}$ suspension the limiting current for $\mathrm{I}^{-}$oxidation on RDE is enhanced by nearly 10 times as compared with those with $\mathrm{LiOH}$ and $\mathrm{Li}_{2} \mathrm{O}_{2}$. The direct oxidation of $\mathrm{LiOOH} \cdot \mathrm{H}_{2} \mathrm{O}$ on $\mathrm{RDE}$ could be excluded as it generated almost zero current in the absence of LiI (Fig. 3a). Thus, such a considerable enhancement is rationalized by the catalytic reaction between the formed $\mathrm{I}_{3}^{-}$and $\mathrm{LiOOH}$ in the vicinity of $\mathrm{RDE}$, which rapidly regenerates $\mathrm{I}^{-}$. In contrast, the presence of $\mathrm{LiOH}$ or $\mathrm{Li}_{2} \mathrm{O}_{2}$ suspension has little influence on the reaction of $\mathrm{I}_{3}^{-}$, consistent with the titration experiment.

The reactions of the various lithium compounds with $\mathrm{I}_{3}^{-}$were substantiated by battery charging test. The cell consists of a cathodic and an anodic compartment, which are separated by a piece of LAGP ceramic membrane (Supplementary Fig. 10a). The powders of $\mathrm{LiOOH} \cdot \mathrm{H}_{2} \mathrm{O}, \mathrm{Li}_{2} \mathrm{O}_{2}$ and $\mathrm{LiOH}$ were loaded on the cathode (carbon felt) before it was fabricated into the cell. The use of $\mathrm{Li}^{+}$-conducting membrane is crucial as it prevents $\mathrm{I}_{3}^{-}$, water and oxygen from crossing-over and parasitically reacting with the $\mathrm{Li}$ metal in the anodic side. As shown in Fig. 3b, the theoretical charging time of $\mathrm{I}^{-}$to $\mathrm{I}_{2}$ is $\sim 7 \mathrm{~h}$, whereas all the three cells present significantly longer charging process $(>30 \mathrm{~h})$, indicating the lithium compounds are involved in the reactions contributing to the charging capacity. In the absence of the above lithium compounds, the reactions of $\mathrm{I}^{-}$in DME electrolyte exhibit two distinct voltage plateaus at $\sim 3.20$ and $3.70 \mathrm{~V}$, corresponding to the formation of $\mathrm{I}_{3}^{-}$and higher order polyiodide to eventually $\mathrm{I}_{2}$, respectively (Supplementary Fig. 11$)^{38}$. In comparison, the LiOOH cell reveals only one prolonged charging plateau at $\sim 3.20 \mathrm{~V}$, which is rational in terms of the titration experiment that the formed $\mathrm{I}_{3}^{-}$could instantaneously be reduced back to $\mathrm{I}^{-}$ by $\mathrm{LiOOH}$ for extended charging, and the cell voltage is determined by the $\mathrm{I}^{-} / \mathrm{I}_{3}^{-}$redox reaction on the electrode. So the overall reaction on the cathode only involves $\mathrm{I}^{-} / \mathrm{I}_{3}^{-}$mediated oxidation of $\mathrm{LiOOH}$, and the capacity is limited by the quantity of material loaded. In comparison, the $\mathrm{Li}_{2} \mathrm{O}_{2}$ cell presents two charging plateaus resembling that of the pure LiI cell (Supplementary Fig. 11), but with the second plateau greatly extended. Such a phenomenon has previously been observed in redox flow lithium-oxygen battery (RFLOB) ${ }^{17}$ and is consistent with the titration that in aprotic electrolyte $\mathrm{I}_{3}^{-}$is unable to rapidly oxidize $\mathrm{Li}_{2} \mathrm{O}_{2}$, which requires a stronger oxidizer such as
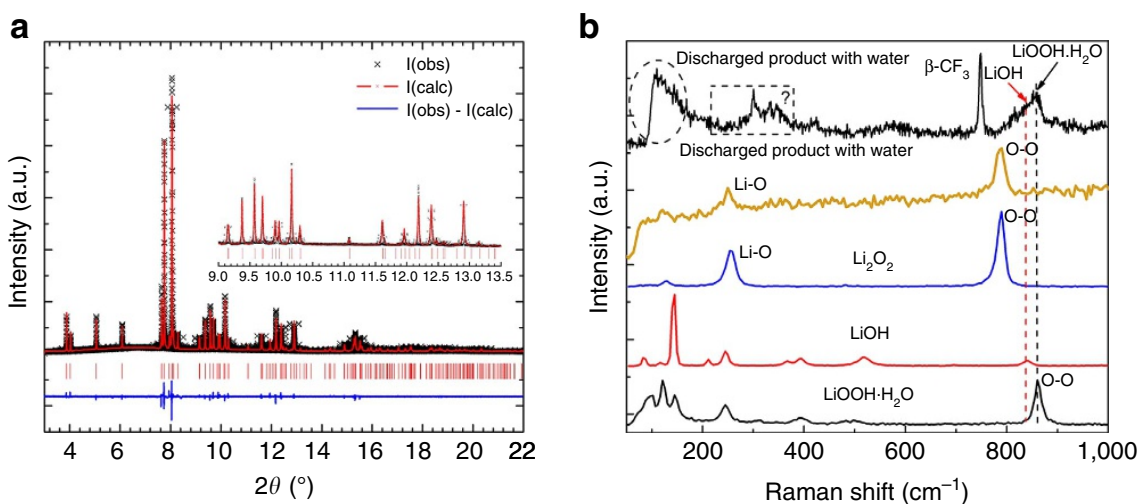

Figure 1 | Characterizations of the various lithium compounds and the discharge product with or without water contamination. (a) Rietveld refinement of the high-resolution X-ray diffraction pattern of the chemically synthesized $\mathrm{LiOOH} \cdot \mathrm{H}_{2} \mathrm{O}$ phase. The wavelength is $\lambda=0.41423 \pm 0.00004 \AA$. The $\mathrm{R}$ factors of Rietveld refinement are $R_{\mathrm{p}}=6.10 \%, R_{\mathrm{wp}}=7.86 \%, \chi^{2}=2.93$. (b) Raman spectra of $\mathrm{Li}_{2} \mathrm{O}_{2}, \mathrm{LiOH}, \mathrm{LiOOH} \cdot \mathrm{H}_{2} \mathrm{O}$ and that of the discharge product collected from the cathode of a $\mathrm{Li}_{-} \mathrm{O}_{2}$ cell without water or containing 9.1 vol. $\% \mathrm{H}_{2} \mathrm{O}$ in the electrolyte. 

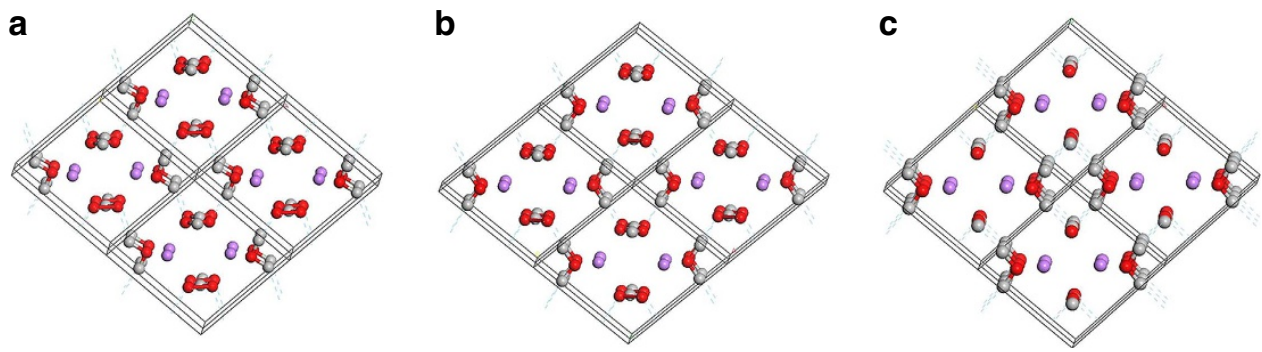

Figure 2 | Comparison of crystal structures between LiOOH $\cdot \mathbf{H}_{\mathbf{2}} \mathbf{O}$ and LiOH $\cdot \mathbf{H}_{\mathbf{2}} \mathbf{O}$. Crystal structure of LiOOH $\cdot \mathrm{H}_{2} \mathrm{O}$ as derived from (a) Rietveld refinement of synchrotron X-ray powder data and (b) from DFT refinement. (c) The crystal structure of $\mathrm{LiOH} \cdot \mathrm{H}_{2} \mathrm{O}$ given by $\mathrm{Hermannson}$ et al. ${ }^{44} \mathrm{Here}$ the primitive cell is shown to emphasize the close relation between the structures of both phases. ( $\mathrm{O}$ : red; $\mathrm{H}$ : grey, Li: magenta). Broken lines indicate the hydrogen bonds stabilizing the structures.
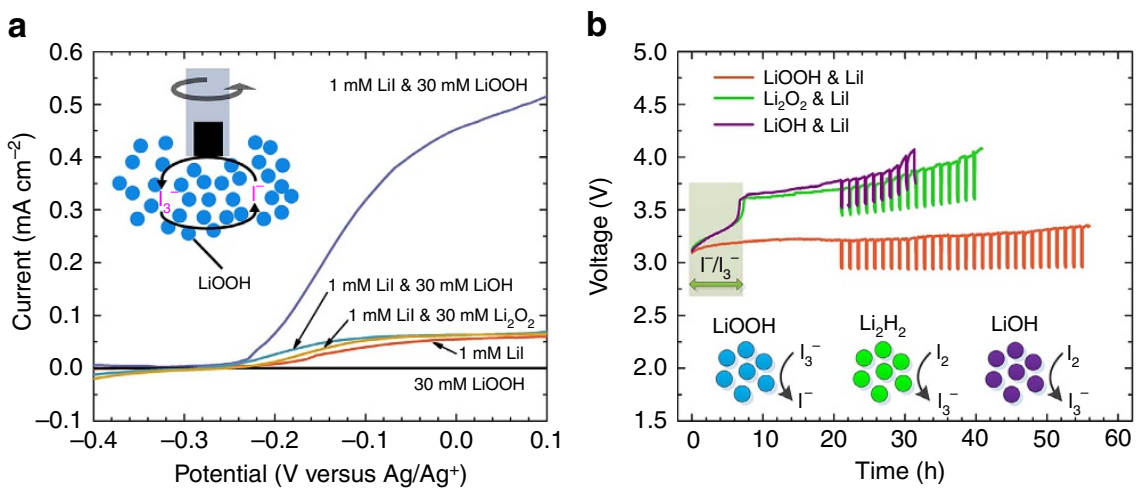

Figure 3 | Electrochemical properties of LiOOH and the comparisons with LiOH and $\mathbf{L i}_{\mathbf{2}} \mathbf{O}_{\mathbf{2}}$. (a) RDE measurements of $1 \mathrm{mM} \mathrm{Lil} \mathrm{in} 0.1 \mathrm{M} \mathrm{LiTFSI} / \mathrm{DME}$ with $30 \mathrm{mM} \mathrm{LiOOH} \cdot \mathrm{H}_{2} \mathrm{O}, \mathrm{Li}_{2} \mathrm{O}_{2}$ or $\mathrm{LiOH}$ dispersed in the solution. For comparison, the same measurements were conducted in the absence of $\mathrm{Lil}$ or lithium compounds suspension in the electrolyte. The rotating rate was 1,200 r.p.m. and the scan rate was $0.01 \mathrm{Vs}^{-1}$. The inset illustrates the catalytic reaction between $\mathrm{LiOOH}$ and $\mathrm{I}_{3}^{-}$upon RDE measurement. (b) The charging curves of $\mathrm{Li}-\mathrm{LiOOH}, \mathrm{Li}_{-} \mathrm{Li}_{2} \mathrm{O}_{2}$ and $\mathrm{Li}-\mathrm{LiOH}$ cells. Lithium foil was used as anode. $\mathrm{LiOOH} \cdot \mathrm{H}_{2} \mathrm{O}$ precipitate, $\mathrm{Li}_{2} \mathrm{O}_{2}$ or $\mathrm{LiOH}$ powder in great excess to $\mathrm{Lil}$ in catholyte was loaded onto the cathode before the cells were assembled. The catholyte was $1 \mathrm{ml} \mathrm{0.5} \mathrm{M} \mathrm{LiTFSI/DME} \mathrm{containing} 40 \mathrm{mM}$ Lil. A LAGP membrane was used to segregate the two cell compartments. The cells were first charged at a constant current of $0.1 \mathrm{~mA} \mathrm{~cm}^{-2}$ for $21 \mathrm{~h}$, and then followed by GITT measurement ( $2 \mathrm{~h}$ charging at the same current plus $10 \mathrm{~min}$ resting).

$\mathrm{I}_{2}$ formed at the higher voltage plateau. The charging of the $\mathrm{LiOH}$ cell is fairly similar to that of $\mathrm{Li}_{2} \mathrm{O}_{2}$, except for slightly larger overpotentials at the higher voltage plateau, presumably a result of sluggish reaction between $\mathrm{LiOH}$ and $\mathrm{I}_{2}$, or more complex reactions ${ }^{22-24}$.

To eliminate the overpotentials imposed by the membrane and other cell components during the charging process, galvanostatic intermittent titration technique (GITT) measurement was performed with the cells after $20 \mathrm{~h}$ charging. The relaxed cell voltage is on average $\sim 2.95$ and $3.55 \mathrm{~V}$ for the $\mathrm{LiOOH}$ and $\mathrm{Li}_{2} \mathrm{O}_{2}$ cells, and is slightly higher for the $\mathrm{LiOH}$ cell, broadly in agreement with the respective potential of $\mathrm{I}^{-} / \mathrm{I}_{3}^{-}$and $\mathrm{I}_{3}^{-} / \mathrm{I}_{2}$ as determined by voltammetry (Supplementary Fig. 12). The above charging tests corroborate the previous comparison of the three compounds with $\mathrm{I}_{3}^{-}$and that $\mathrm{LiOOH}<\mathrm{Li}_{2} \mathrm{O}_{2}<\mathrm{LiOH}$ in terms of oxidation capability.

Characterization of $\mathrm{Li}-\mathrm{O}_{2}$ battery with water contamination. In order to verify the formation of $\mathrm{LiOOH}$ as an oxygen reduction product in moisture-contaminated $\mathrm{Li}^{-} \mathrm{O}_{2}$ battery, water was deliberately introduced into the aprotic catholyte of $\mathrm{Li}_{2} \mathrm{O}_{2}$ cells. As shown in Fig. 4a, the presence of water seems to be advantageous to the reduction of overpotential during the $10 \mathrm{~h}$ discharging process. With increasing water content in the electrolyte, the discharging plateau shifts upwards. The charging curves for all the cells predominantly present two voltage plateaus at $\sim 3.50 \mathrm{~V}$ and $3.85 \mathrm{~V}$, respectively. The lower voltage plateau is assigned to the oxidation of $\mathrm{I}^{-}$to $\mathrm{I}_{3}^{-}$, whereas owing to surface passivation of the electrode as generally observed in aprotic Li-oxygen batteries, the overpotential is considerably higher than that observed in Fig. 3b. The maximum charging time for $\mathrm{I}^{-}$to $\mathrm{I}_{3}^{-}$is $\sim 4.5 \mathrm{~h}$, so the extended charging would be a result of the catalytic reaction of $\mathrm{I}_{3}^{-}$with the discharge product, in which LiOOH was identified by Raman spectroscopy when probing the electrode after $10 \mathrm{~h}$ discharge (Fig. $1 \mathrm{~b}$ ).

However, the prolonged additional $4-5 \mathrm{~h}$ charging time at $\sim 3.50 \mathrm{~V}$ could not account for the $10 \mathrm{~h}$ discharge, for which around half the discharge product seemingly remains intact with $\mathrm{I}_{3}^{-}$. When the cells were further charged to a higher voltage, where the reaction of $\mathrm{I}_{3}^{-} / \mathrm{I}_{2}$ prevails, a second voltage plateau appeared at $\sim 3.85 \mathrm{~V}$ with evidently extended charging for another $4-5 \mathrm{~h}$. On the basis of the previous charging tests, either $\mathrm{LiOH}$ or $\mathrm{Li}_{2} \mathrm{O}_{2}$ may contribute to this process, whereas considering $\mathrm{Li}_{2} \mathrm{O}_{2}$ is instable in the presence of water, this extra capacity is deemed to be stemming from $\mathrm{LiOH}\left(\right.$ or $\mathrm{LiOH} \cdot \mathrm{H}_{2} \mathrm{O}$ ). This is reasonable in terms of reaction (1), and that the discharge product of aprotic $\mathrm{Li}-\mathrm{O}_{2}$ battery, $\mathrm{Li}_{2} \mathrm{O}_{2}$, is converted into two distinct compounds co-existing in water-contaminated cells, of which $\mathrm{LiOOH} \cdot \mathrm{H}_{2} \mathrm{O}$ reacts with $\mathrm{I}_{3}^{-}$at a lower voltage, whereas $\mathrm{LiOH} \cdot \mathrm{H}_{2} \mathrm{O}$ reacts with $\mathrm{I}_{2}$ at a higher voltage in a two-stage charging process. The presence of $\mathrm{LiOOH}$ and $\mathrm{LiOH}$ in the discharge product was confirmed by ATR-FTIR measurement (Supplementary Fig. 13), in which the characteristic peaks of $\mathrm{LiOH}$ and $\mathrm{LiOOH} \cdot \mathrm{H}_{2} \mathrm{O}$ are clearly identified upon redoxassisted ORR reaction in the presence of water. 
a

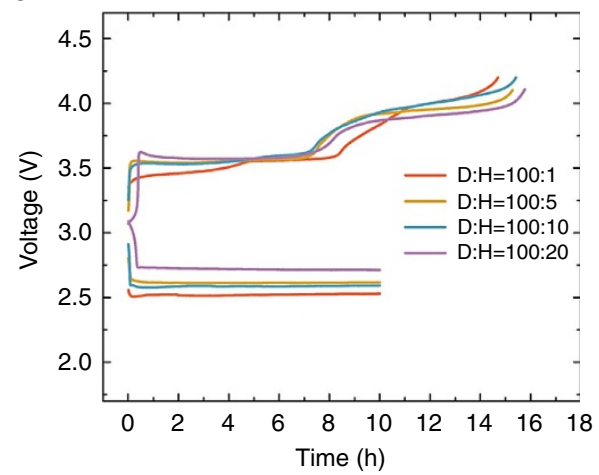

b

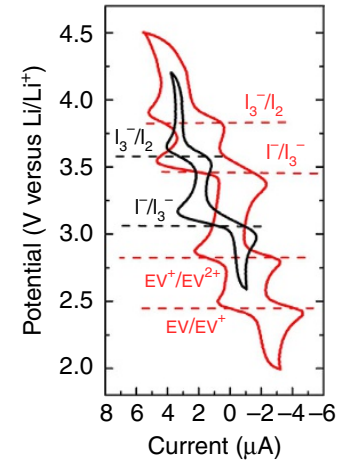

c

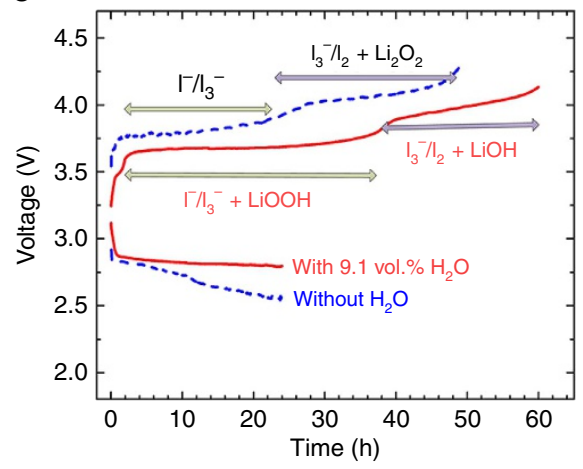

Figure 4 | Electrochemical performance of $\mathbf{L i}-\mathbf{O}_{\mathbf{2}}$ cells with different $\mathbf{H}_{\mathbf{2}} \mathbf{O}$ content in the catholyte. (a) The charge-discharge curves of watercontaminated $\mathrm{Li}_{-} \mathrm{O}_{2}$ batteries. The catholyte consisted of $0.5 \mathrm{ml} 50 \mathrm{mM}$ Lil and $0.5 \mathrm{M}$ LiTFSI in DME. Different amount of water was introduced in the catholyte. D:H denotes the volume ratio of DME and $\mathrm{H}_{2} \mathrm{O}$. (b) The cyclic voltammograms of $2.5 \mathrm{mM}$ Lil in $0.5 \mathrm{M} \mathrm{LiTFSI/DME}$ and $2.5 \mathrm{mM} \mathrm{EVI}$ in $0.5 \mathrm{M}$ LiTFSI/ DEGDME-DMSO (1:1 v/v). Pt disc and plate were used as the working and counter electrode, respectively. The scan rate was $0.02 \mathrm{Vs}-1$. (c) The charge-discharge curves of redox flow $\mathrm{Li}_{-} \mathrm{O}_{2}$ battery using $\mathrm{EVI}_{2}$ as the redox mediator. The catholyte consisted of $4 \mathrm{ml} 15 \mathrm{mM} \mathrm{EVI}$ and $0.5 \mathrm{M} \mathrm{LiTFSI}$ in DEGDME-DMSO $(1: 1 \mathrm{v} / \mathrm{v})$ with or without $9.1 \mathrm{vol} . \% \mathrm{H}_{2} \mathrm{O}$. The anolyte was $0.5 \mathrm{M} \mathrm{LiTFSI} \mathrm{in} \mathrm{DEGDME.} \mathrm{The} \mathrm{current} \mathrm{was} \mathrm{set} \mathrm{at} 0.1 \mathrm{~mA}^{-2}$ for all the above galvanostatic measurements.

When the charging curves in Fig. 4a are examined closely, one may notice multiple voltage steps at each voltage plateaus, which is ascribed to the direct oxidation of $\mathrm{LiOOH} \cdot \mathrm{H}_{2} \mathrm{O}$ and $\mathrm{LiOH} \cdot \mathrm{H}_{2} \mathrm{O}$ on the cathode alongside the reactions with redox mediators in the electrolyte. To avoid the complexity and ambiguity, a RFLOB cell was fabricated, which employed ethyl viologen diiodide $\left(\mathrm{EVI}_{2}\right)$ as a bifunctional redox mediator for both the ORR and OER reactions (Fig. 4b). One significant advantage for RFLOB over the conventional Li- $\mathrm{O}_{2}$ battery is that upon discharging $\mathrm{O}_{2}$ is fed into a gas diffusion tank (GDT) in which it is reduced by $\mathrm{EV}^{+}$when the catholyte circulates through (Supplementary Fig. 10c). As a result, the discharge product is chemically formed in the tank instead of being deposited on the electrode surface. Upon charging, the parallel reactions of these materials on the electrode are thus obviated. As the voltage profiles in Fig. 4c shows, the presence of water in the catholyte considerably reduces the cell overpotential, similar to that observed in static cells. The discharging process of the flow cells involves the reduction of $\mathrm{EV}^{2+}$ on the electrode and the associated ORR reaction in GDT. Upon charging, the dry cell exhibits two voltage plateaus with the first one relating to the oxidation of $\mathrm{I}^{-}$to $\mathrm{I}_{3}^{-}$, and the second with extended capacity originating from the oxidation of $\mathrm{I}_{3}^{-}$to $\mathrm{I}_{2}$ and the reaction between $\mathrm{Li}_{2} \mathrm{O}_{2}$ and $\mathrm{I}_{2}$, which is consistent with our previous study ${ }^{17}$. In comparison, although the water-contaminated flow cell also shows two clearly defined plateaus during the charging process, the capacities for both plateaus stretch nearly equally beyond that of the redox mediators, implying two distinct reactions with $\mathrm{I}_{3}^{-}$and $\mathrm{I}_{2}$ take place at the two plateaus respectively.

The redox-targeting reactions of $\mathrm{LiOOH}$ with $\mathrm{I}_{3}^{-}$and $\mathrm{LiOH}$ with $\mathrm{I}_{2}$ were further investigated with $\mathrm{UV}$-Vis and mass spectrometry. After mixing with $\mathrm{LiOOH} \cdot \mathrm{H}_{2} \mathrm{O}$ suspension in DME, the characteristic absorption peak of $\mathrm{I}_{3}^{-}$at $364 \mathrm{~nm}$ (extended to the visible region, Supplementary Fig. 14a) vanished. As a result, the solution became nearly colourless. Meanwhile, the mass spectrometric measurement in Supplementary Fig. 15a shows that $\mathrm{O}_{2}$ evolves instantaneously upon mixing $\mathrm{I}_{3}^{-}$with $\mathrm{LiOOH} \cdot \mathrm{H}_{2} \mathrm{O}$. In a separate test, after adding excessive $\mathrm{LiOH}$ into a solution of $\mathrm{I}_{2}$ in DME/ $\mathrm{H}_{2} \mathrm{O}(10: 1)$ and stirring for $1 \mathrm{~h}$, the absorption of the $\mathrm{I}_{2}$ solution became fairly identical to that of $\mathrm{I}_{3}^{-}$ (Supplementary Fig. 14b). That is, the absorption at $400-500 \mathrm{~nm}$ was greatly attenuated with only the characteristic peak of $\mathrm{I}_{3}^{-}$ present, indicating the existence of $\mathrm{I}_{3}^{-}$after reaction. We noticed $\mathrm{IO}_{3}^{-}$was detected to be the main product of the reaction between $\mathrm{I}_{2}$ and $\mathrm{LiOH}$ in water-based electrolyte in the literature ${ }^{26}$. The involved reaction is, $3 \mathrm{I}_{2}+6 \mathrm{LiOH} \rightarrow 5 \mathrm{LiI}+\mathrm{LiIO}_{3}+3 \mathrm{H}_{2} \mathrm{O}$. Considering both $\mathrm{I}^{-}$and $\mathrm{IO}_{3}^{-}$are colourless, the above reaction seems unlikely to be predominant in the $\mathrm{DME} / \mathrm{H}_{2} \mathrm{O}$ (10:1)-based electrolyte. The mass spectrometric measurement of the reaction between $\mathrm{LiOH}$ and $\mathrm{I}_{2}$ was conducted in two different solutions. As shown in Supplementary Fig. 15b, oxygen evolution was observed instantaneously after $\mathrm{I}_{2}$ was injected into $2 \mathrm{M} \mathrm{LiOH}$ suspension in $\mathrm{DME} / \mathrm{H}_{2} \mathrm{O} \quad(10: 1)$, further confirming the irrelevance of the above reaction in the $\mathrm{DME} / \mathrm{H}_{2} \mathrm{O}$ (10:1)-based electrolyte. Therefore, $\mathrm{O}_{2}$ evolution is deemed part of the reactions of $\mathrm{LiOOH}$ with $\mathrm{I}_{3}^{-}$and $\mathrm{LiOH}$ with $\mathrm{I}_{2}$ during the charging process of water-contaminated $\mathrm{Li}-\mathrm{O}_{2}$ cells.

Two-stage charging reactions in water-contaminated $\mathrm{Li}-\mathrm{O}_{2}$ cells. On the basis of the above analysis, the following reactions are thus proposed to expound the discharging and the two-stage charging processes in the water-contaminated cell:

Discharging process (ORR reaction):

$$
2 \mathrm{Li}^{+}+\mathrm{O}_{2}+3 \mathrm{H}_{2} \mathrm{O}+2 \mathrm{e}^{-} \rightarrow \mathrm{LiOOH} \cdot \mathrm{H}_{2} \mathrm{O}+\mathrm{LiOH} \cdot \mathrm{H}_{2} \mathrm{O}
$$

Charging process (OER reaction):

$$
\begin{gathered}
3 \mathrm{I}^{-} \rightarrow \mathrm{I}_{3}^{-}+2 \mathrm{e}^{-} \\
4 \mathrm{LiOOH} \cdot \mathrm{H}_{2} \mathrm{O}+2 \mathrm{LiI}_{3} \rightarrow 6 \mathrm{LiI}+3 \mathrm{O}_{2}+6 \mathrm{H}_{2} \mathrm{O} \\
\mathrm{I}_{3}^{-} \rightarrow 3 / 2 \mathrm{I}_{2}+\mathrm{e}^{-} \\
4 \mathrm{LiOH} \cdot \mathrm{H}_{2} \mathrm{O}+6 \mathrm{I}_{2} \rightarrow 4 \mathrm{LiI}_{3}+\mathrm{O}_{2}+6 \mathrm{H}_{2} \mathrm{O}
\end{gathered}
$$

Reaction (4) indicates that equimolar amounts of $\mathrm{LiOOH}$ and $\mathrm{LiOH}$ are formed in the discharging process, which is evidenced by the identical capacity extension in the two-stage charging process in Fig. 4a,c. $\mathrm{OOH}^{-}$has been proposed in battery reactions in several studies as a result of $\mathrm{H}_{2} \mathrm{O}$ dissociation or electrolyte decomposition ${ }^{25,28,32,39}$, whereas none of them explicitly indicates $\mathrm{LiOOH}$ or $\mathrm{LiOOH} \cdot \mathrm{H}_{2} \mathrm{O}$ as a distinct discharge product, nor its structural and electrochemical properties. Besides, we have noticed that water has substantial influence on the morphology of the discharge product. When 9.1 vol.\% water was added into the electrolyte, rod and cube-like 
crystals with clear edges were observed after discharge, whereas crystals formed in dry electrolyte tested in separate cells are agglomerated into round-shaped particulates (Supplementary Fig. 16). Reactions (5) and (7) describe the two-stage charging process, associated with the redox-targeting reactions with $\mathrm{LiOOH} \cdot \mathrm{H}_{2} \mathrm{O}$ (6) and $\mathrm{LiOH} \cdot \mathrm{H}_{2} \mathrm{O}$ (8), respectively. Reaction (6) represents a disproportionation reaction with $\frac{3}{4}$ of the peroxide being oxidized to $\mathrm{O}_{2}$, and the remaining $\frac{1}{4}$ reduced to $\mathrm{H}_{2} \mathrm{O}$. Additional $\frac{1}{4} \mathrm{O}_{2}$ is produced in reaction (8) via a 4-electron process, making up the total $\mathrm{O}_{2}$ consumption in the discharging reaction (4). A consequence of such two-step reactions is that both the voltage efficiency and energy efficiency are compromised.

\section{Discussion}

The above study unveils an intriguing picture of the ORR and OER reactions for water-contaminated $\mathrm{Li}-\mathrm{O}_{2}$ batteries, for which the transfer of protons from water leads to the formation of a new compound- $\mathrm{LiOOH} \cdot \mathrm{H}_{2} \mathrm{O}$, while the left-over $\mathrm{OH}^{-}$prompts the formation of an equimolar amount of $\mathrm{LiOH}\left(\right.$ or $\mathrm{LiOH} \cdot \mathrm{H}_{2} \mathrm{O}$ ). More precisely, such a situation might be called water contamination at 'neutral' conditions. It would be interesting to consider the scenarios under varying proton concentrations. For instance, in weakly acidic condition, it is likely that $\mathrm{Li}^{+}+$ $\mathrm{O}_{2}+\mathrm{H}^{+}+2 \mathrm{e}^{-}+\mathrm{H}_{2} \mathrm{O} \rightarrow \mathrm{LiOOH} \cdot \mathrm{H}_{2} \mathrm{O}$, so that $\mathrm{LiOOH} \cdot \mathrm{H}_{2} \mathrm{O}$ would again be the discharge product with $\mathrm{pH}$-dependent equilibrium potential. However, when excessive protons present in the catholyte, it appears plausible that $2 \mathrm{H}^{+}+\mathrm{O}_{2}+2 \mathrm{e}^{-} \rightarrow \mathrm{HOOH}$. That is, the remaining $\mathrm{Li}$ atom in $\mathrm{LiOOH} \cdot \mathrm{H}_{2} \mathrm{O}$ could be knocked out to form $\mathrm{H}_{2} \mathrm{O}_{2}$. At the other extreme, when extra $\mathrm{OH}^{-}$is introduced into the catholyte, the proton in $\mathrm{LiOOH}$ would be removed and as reported for water-based alkaline electrolytes ${ }^{40}$, the formation of $\mathrm{Li}_{2} \mathrm{O}_{2}$ would be favoured, for which the redox potential of the overall reaction becomes $\mathrm{pH}$-independent. Figure 5 illustrates the plausible battery reactions of 'proton-contaminated' $\mathrm{Li}-\mathrm{O}_{2}$ cells which may predominate at different $\left[\mathrm{H}^{+}\right]$. We believe systematic studies on the impact of protons on the ORR and OER reactions would disclose deeper insights into the mechanistic understanding of the battery chemistry of Li-air batteries.

Considering the $\mathrm{LiOOH} \cdot \mathrm{H}_{2} \mathrm{O}$ has greater reactivity towards the OER reaction, which substantially brings down the charging overpotential (Fig. 3b), it is of immediate importance to contemplate the implications of the new compound for the operation of the $\mathrm{Li}-\mathrm{O}_{2}$ battery. However, this seems not intuitively straightforward. A formation of $\mathrm{LiOOH} \cdot \mathrm{H}_{2} \mathrm{O}$ during the discharging process requires protons which are not available from the anode. Although the moisture in air could be a natural source of protons, the accumulation of water in the catholyte during the charging process makes it unsustainable. In addition, the formation of $\mathrm{LiOOH} \cdot \mathrm{H}_{2} \mathrm{O}$ in water- or alcohol-containing electrolytes may provide an alternative approach of reactions for water-based $\mathrm{Li}-\mathrm{O}_{2}$ battery, in which the 4-electron process is generally considered. As water could be precluded as a reactant from the 2-electron process of $\mathrm{LiOOH}$ (that is, in acidic and basic conditions), it may in theory boost the energy density and energy efficiency of water-based $\mathrm{Li}-\mathrm{O}_{2}$ cells.

A distinct battery chemistry was discovered for water-contaminated $\mathrm{Li}-\mathrm{O}_{2}$ battery, from which a new lithium compound- $\mathrm{LiOOH} \cdot \mathrm{H}_{2} \mathrm{O}$, was identified as a predominant oxygen reduction product and structurally characterized. When iodide is used as the OER redox catalyst in the watercontaminated $\mathrm{Li}-\mathrm{O}_{2}$ cell, the equimolar amounts of $\mathrm{LiOOH} \cdot \mathrm{H}_{2} \mathrm{O}$ and $\mathrm{LiOH} \cdot \mathrm{H}_{2} \mathrm{O}$ formed in the discharging process are oxidized stepwise by $\mathrm{I}_{3}^{-}$and $\mathrm{I}_{2}$, leading to a two-stage charging process.
This study discloses that the moisture fed into the cell does not pose immediate adverse impact to the battery operation, so long as the lithium anode is properly protected. On the basis of this new battery chemistry, a panoramic view of the ORR/OER reactions at different $\left[\mathrm{H}^{+}\right]$is conceived, which is anticipated to provide deeper insights into the mechanistic understanding of the chemistry of Li-air batteries. For that, we believe a more systematic study would be desired in future to understand the factors such as water content, $\left[\mathrm{H}^{+}\right]$, type of redox mediators and so on, that influence the formation of $\mathrm{LiOOH} \cdot \mathrm{H}_{2} \mathrm{O}$ or other oxygen reduction products.

\section{Methods}

Materials. $\mathrm{LiOH}$ (98\%, Sigma-Aldrich), $\mathrm{Li}_{2} \mathrm{O}_{2}$ (90\%, Sigma-Aldrich), and $\mathrm{H}_{2} \mathrm{O}_{2}$ (35\% (w/w) in $\mathrm{H}_{2} \mathrm{O}$, Alfa Aesar) were used in the titration experiments. $\mathrm{LiOH}$ (98\%, Sigma-Aldrich) and $\mathrm{H}_{2} \mathrm{O}_{2}\left(35 \%(w / w)\right.$ in $\mathrm{H}_{2} \mathrm{O}$, Alfa Aesar) were used for the preparation of $\mathrm{LiOOH} \cdot \mathrm{H}_{2} \mathrm{O}$. DME( $99 \%$, Sigma-Aldrich) and dimethyl carbonate (anhydrous, $>99 \%$, Sigma-Aldrich) were used to get the precipitation of $\mathrm{LiOOH} \cdot \mathrm{H}_{2} \mathrm{O}$. Diethylene glycol dimethyl ether (DEGDME, 99\%, Sigma-Aldrich), DME (99\%, Sigma-Aldrich), dimethyl sulfoxide (DMSO, 99.9\%, Sigma-Aldrich) and lithium bis(trifluoromethane)sulfonimide (LiTFSI, 99.95\%, Sigma-Aldrich) were used as solvent and lithium salt for electrolyte preparation. LiI (99\%, Sigma-Aldrich) and $\mathrm{EVI}_{2}$ (99\%, Sigma-Aldrich) were used as redox mediators in $\mathrm{Li}-\mathrm{O}_{2}$ batteries. $\mathrm{A} \mathrm{Li}^{+}$-conducting ceramic membrane (LAGP, area $2 \mathrm{~cm} \times 2 \mathrm{~cm}$, thickness $0.5 \mathrm{~mm}$ ) was used as separator in $\mathrm{Li}-\mathrm{O}_{2}$ batteries. Prior to use, all the above chemicals were stored in an argon-filled glove box without exposure to air.

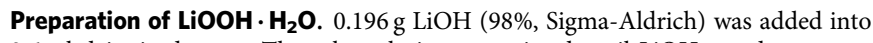
$2.6 \mathrm{ml}$ deionized water. Then the solution was stirred until $\mathrm{LiOH}$ powder was dissolved completely. With good stirring, $1.4 \mathrm{ml} \mathrm{H}_{2} \mathrm{O}_{2}$ solution $(35 \% \mathrm{w} / \mathrm{w}$, Alfa Aesar) were added dropwise into the above $\mathrm{LiOH}$ solution over $30 \mathrm{~min}$, which resulted in $2 \mathrm{M} \mathrm{LiOOH} \cdot \mathrm{H}_{2} \mathrm{O}$ solution in water. In order to retrieve solid $\mathrm{LiOOH} \cdot \mathrm{H}_{2} \mathrm{O}$ from the solution, $2 \mathrm{ml} \mathrm{DME}$ were added dropwise into $1 \mathrm{ml}$ of the above $\mathrm{LiOOH} \cdot \mathrm{H}_{2} \mathrm{O}$ solution with stirring for $10 \mathrm{~min}$. During the process, a white $\mathrm{LiOOH} \cdot \mathrm{H}_{2} \mathrm{O}$ precipitate appeared and sedimented. In the RDE and battery measurements, $2 \mathrm{M} \mathrm{LiOOH} \cdot \mathrm{H}_{2} \mathrm{O}$ solution in water was employed directly to prepare suspension of $\mathrm{LiOOH} \cdot \mathrm{H}_{2} \mathrm{O}$. For the Raman and XRD measurements, wet $\mathrm{LiOOH} \cdot \mathrm{H}_{2} \mathrm{O}$ particles were separated from the supernatant after centrifugation and gently dried in a vacuum oven at room temperature for $12 \mathrm{~h}$.

Assembly of $\mathbf{L i}-\mathrm{O}_{\mathbf{2}}$ battery. Assembly of static $\mathrm{Li}^{-} \mathrm{O}_{2}$ battery: Lithium foil and carbon felt were used as the anode and cathode, respectively. The electrochemical cell was fabricated by sandwiching the lithium foil and carbon felt in a cell stack, in which the two electrodes were separated by a LAGP membrane mounted on a Teflon frame (Supplementary Fig. 6). The effective area of the membrane was $1 \times 1 \mathrm{~cm}^{2}$. The anodic and cathodic end plates were made of stainless steel and titanium metal (with holes as $\mathrm{O}_{2}$ inlet and outlet), respectively, to prevent corrosion caused by the redox species. The anodic compartment was filled with electrolyte consisting of $0.5 \mathrm{M}$ LiTFSI/DEGDME and the cathodic compartment was filled with $0.5-0.7 \mathrm{ml}$ of $0.5 \mathrm{M}$ LiTFSI/DME with around $40-50 \mathrm{mM} \mathrm{LiI}$ and varying quantity of water. For water-containing electrolyte, water was mixed uniformly with the electrolyte before injected into the cell. After the $\mathrm{Li}-\mathrm{O}_{2}$ cell was assembled, the electrolyte was introduced into the cell, which was then tested in oxygen bag filled with pure oxygen.

Assembly of redox flow $\mathrm{Li}-\mathrm{O}_{2}$ battery: Redox flow $\mathrm{Li}-\mathrm{O}_{2}$ cell consists of a battery stack and a GDT. The procedure of fabricating the cell stack is the same to the static $\mathrm{Li}-\mathrm{O}_{2}$ cell. The cell stack was connected to the GDT tank by Teflon tubing, through which the catholyte was circulated between the cell and GDT tank by a peristaltic pump (Supplementary Fig. 6). The anolyte was 0.5 M LiTFSI/DEGDME The catholyte was $15 \mathrm{mM} \mathrm{EVI}_{2}$ in $0.5 \mathrm{M} \mathrm{LiTFSI} / \mathrm{DEGDME}-\mathrm{DMSO}(1: 1 \mathrm{v} / \mathrm{v})$ with or without 9.1 vol. $\% \mathrm{H}_{2} \mathrm{O}$. DMSO was used to reduce the volatility of the catholyte. The volume of catholyte was $4 \mathrm{ml}$. Constant $\mathrm{O}_{2}$ flow was provided to the GDT tank $\left(\mathrm{O}_{2}\right.$ pressure $\left.\sim 1 \mathrm{~atm}\right)$ during the discharging process.

Electrochemical measurements. The RDE measurements were conducted by using a PINE AFMSRCE rotator. The electrolyte was $1 \mathrm{mM} \mathrm{LiI}$ in $0.1 \mathrm{M}$

LiTFSI/DME with $30 \mathrm{mM} \mathrm{LiOOH} \cdot \mathrm{H}_{2} \mathrm{O}, \mathrm{Li}_{2} \mathrm{O}_{2}$ or $\mathrm{LiOH}$ dispersed in the solution. For comparison, the same measurements were conducted in the absence of LiI or lithium compounds suspension in the electrolyte solution. Pt disc (diameter $12 \mathrm{~mm}$ ) and Pt plate were used as working and counter electrode, respectively. And $\mathrm{Ag} / \mathrm{AgNO}_{3}$ electrode was used as reference electrode. The rotating rate was 1,200 r.p.m. and the scan rate was $0.01 \mathrm{~V} \mathrm{~s}^{-1}$.

The cyclic voltammetry measurements for $2.5 \mathrm{mM}$ LiI in $0.5 \mathrm{M}$ LiTFSI/DME and $2.5 \mathrm{mM} \mathrm{EVI}_{2}$ in $0.5 \mathrm{M}$ LiTFSI/DEGDME-DMSO $(1: 1 \mathrm{v} / \mathrm{v})$ were conducted with a scan rate of $0.02 \mathrm{~V} \mathrm{~s}^{-1}$. The working electrode was Pt disc electrode. Both counter and reference electrodes were Li metal. Differential pulse voltammetry 
a

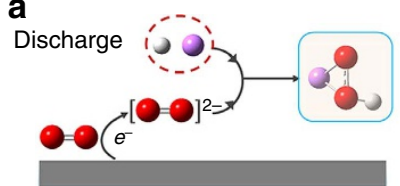

Carbon felt

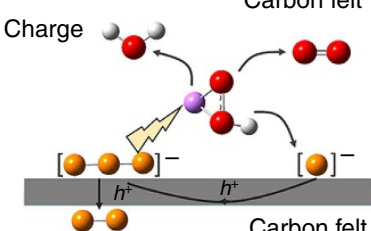

b

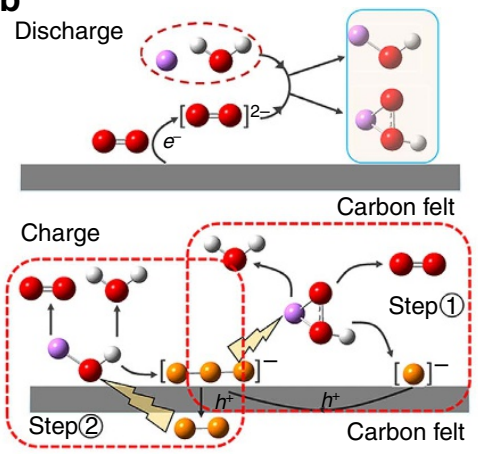

C

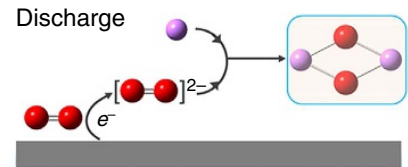

Carbon felt

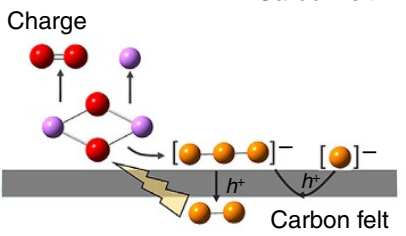

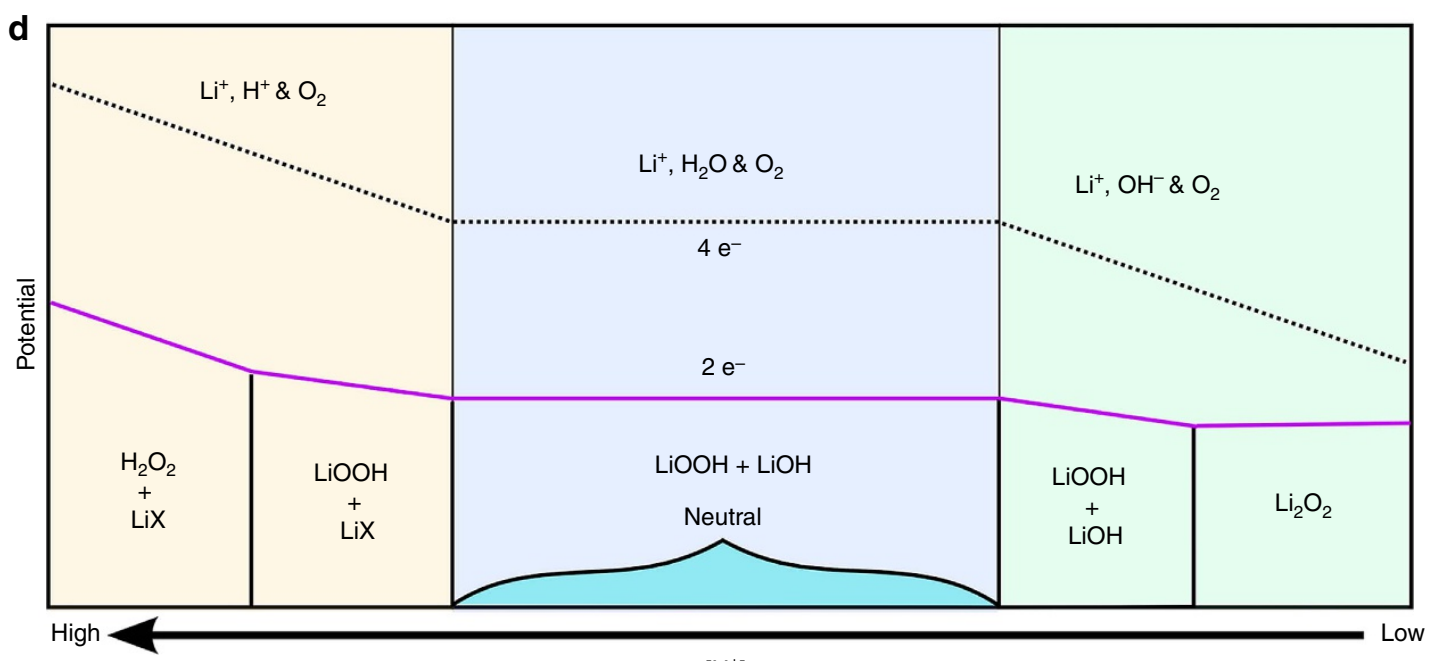

$\left[\mathrm{H}^{+}\right]$

Figure 5 | The proposed mechanism of proton-contaminated Li-02 batteries and Pourbaix diagram with different proton concentration. The proposed mechanisms of the charging and discharging processes in 'proton-contaminated' aprotic Li- $\mathrm{O}_{2}$ battery at (a) acidic, (b) neutral and (c) basic conditions. lodide is included to mediate the OER reaction. Elements in the ball-and-stick model: red-oxygen; purple-lithium; write-hydrogen; yellow-iodine. (d) A sketch of the Pourbaix diagram showing the predominant battery chemistries of $\mathrm{Li}_{2} \mathrm{O}_{2}$ cell at different $\left[\mathrm{H}^{+}\right]$. The 4-electron process shown in dotted line is just for reference and the potential relative to that of the two-electron process has no physical significance. $\mathrm{HX}$ is the acid introduced in the electrolyte.

measurements of LiI were conducted at a variety of water contents. The electrolyte was $5 \mathrm{mM}$ LiI in $0.5 \mathrm{M} \mathrm{LiTFSI} / \mathrm{DME}$ with different water contents $\left(\mathrm{DME}: \mathrm{H}_{2} \mathrm{O}\right.$ are $100: 0,100: 1,100: 5,100: 10,100: 20,100: 30,100: 50,100: 100, \mathrm{v} / \mathrm{v})$. The working and the counter electrode were Pt disc and Pt plate electrode, respectively. The reference electrode was $\mathrm{Ag} / \mathrm{AgNO}_{3}$ electrode. The step potential is $0.005 \mathrm{~V}$ and the modulation amplitude is $0.025 \mathrm{~V}$. All the above measurements were performed on an Autolab electrochemical workstation (Metrohm Autolab, PGSTAT302N). The charge and discharge tests were conducted on an Arbin battery tester. The battery was tested at a constant current of $0.1 \mathrm{~mA} \mathrm{~cm}^{-2}$.

Other characterizations. Raman spectra were measured by a confocal Raman system with $532 \mathrm{~nm}$ laser excitation (WITec Instruments Corp, Germany). Samples for Raman spectroscopic measurement include gently dried $\mathrm{LiOOH} \cdot \mathrm{H}_{2} \mathrm{O}$ powder, powders of the as-purchased $\mathrm{LiOH}$ and $\mathrm{Li}_{2} \mathrm{O}_{2}$, as well as $35 \% \mathrm{H}_{2} \mathrm{O}_{2}$ solution. The Raman spectrum of the cathode (carbon felt) in the $\mathrm{Li}^{-} \mathrm{O}_{2}$ batteries was also measured immediately after disassembling the fully discharged static $\mathrm{Li}^{-} \mathrm{O}_{2}$ cells. For the $\mathrm{Li}-\mathrm{O}_{2}$ cells with water-free electrolyte, the cathode was washed and dried in a vacuum chamber prior to Raman measurement. All the above samples were loaded on a piece of sapphire for Raman measurement. FTIR spectra were collected via PerkinElmer Frontier MIR/FIR system by 16 scans with a nominal resolution of $1 \mathrm{~cm}^{-1}$ through an ATR mode. In the in situ measurement of the redox-targeting reaction product between $\mathrm{EV}^{+}$and $\mathrm{O}_{2}$, a flow cell with two inlets and one outlet (two for liquid and one for oxygen) was used. UV-Vis spectroscopic measurements were conducted on a UV-Vis spectrophotometer (Shimadzu 1800). Mass spectrometric measurements were conducted on a Hiden analytical QGA (HAS-301-1376A). There are one outlet and two inlets of the reactor for carrying gas and injecting reactant.

The high-energy XRD measurements were performed on the beam line 11-ID-C at the Advanced Photon Source, Argonne National Laboratory. A monochromator with a $\mathrm{Si}$ (113) single crystal was used to provide an X-ray beam with the energy of $115 \mathrm{keV}$. High-energy X-ray with a beam size of $0.2 \mathrm{~mm} \times 0.2 \mathrm{~mm}$ and wavelength of $0.10725 \AA$ was used to obtain two-dimensional diffraction patterns in the transmission geometry. X-rays were collected with a Perkin-Elmer large-area detector placed at $1,800 \mathrm{~mm}$ from the sample. The obtained two-dimensional diffraction patterns were calibrated using a standard $\mathrm{CeO}_{2}$ sample and converted to one-dimensional patterns using Fit2D software. In order to figure out the structure of the obtained $\mathrm{LiOOH} \cdot \mathrm{H}_{2} \mathrm{O}$ sample, the high-resolution X-ray powder diffraction pattern of $\mathrm{LiOOH} \cdot \mathrm{H}_{2} \mathrm{O}$ was taken at 11-BM, Advanced Photon Source, Argonne National Lab, whereas the wavelength of the X-ray is $0.41423 \AA$. The samples were measured in air without protection. For the stability test, XRD measurements were carried out on a Bruker D8 with $\mathrm{Cu}$ $\mathrm{K} \alpha 1$ radiation $(\lambda=0.154059 \mathrm{~nm})$. The samples were measured in air without protection.

Theoretical calculations. DFT calculations were carried out with B3LYP hybrid exchange-correlation functional in combination with the quadruple-zeta polarized valence basis set augmented with diffuse functions, aug-cc-pVQZ, using the Gaussian 09 programme suite ${ }^{41,42}$. The scaled quantum mechanics force field procedure was used to analyse vibrational bands of all fundamentals. The calculated frequencies were scaled by a factor of 0.9852 for frequencies below $2,000 \mathrm{~cm}^{-1}$ (ref. 43). Scaling harmonic vibrational frequencies is an effective way to facilitate comparison with experimentally observed frequencies. A scaling factor of 0.9852 was recommended for the B3LYP/aug-cc-pVQZ level of theory for which the corresponding root mean square error relative to the experimental frequencies was report to be $8 \mathrm{~cm}^{-1}$ (ref. 43). The calculated scaled frequencies for the $\mathrm{O}-\mathrm{O}$ stretch are: $838.0\left(\mathrm{LiOOH} \cdot \mathrm{H}_{2} \mathrm{O}\right), 827.6(\mathrm{LiOOLi}), 934.9(\mathrm{HOOH}) \mathrm{cm}^{-1}$. The structure and vibration frequencies of $\mathrm{LiOOH} \cdot \mathrm{H}_{2} \mathrm{O}$ are also verified against partial phonon density of states generated using Phonopy package with Vienna ab initio simulation package and GGA-PBE exchange and correlation potential.

Data availability. The authors declare that data supporting the findings of this study are available within the paper and its supplementary information file or from the corresponding author on reasonable request. 


\section{References}

1. Girishkumar, G., McCloskey, B., Luntz, A., Swanson, S. \& Wilcke, W. Lithium-air battery: promise and challenges. J. Phys. Chem. Lett. 1, 2193-2203 (2010).

2. Abraham, K. M. \& Jiang, Z. A polymer electrolyte-based rechargeable lithium/oxygen battery. J. Electrochem. Soc. 143, 1-5 (1996).

3. Read, J. Ether-based electrolytes for the lithium/oxygen organic electrolyte battery. J. Electrochem. Soc. 153, A96-A100 (2006).

4. Ogasawara, T., Débart, A., Holzapfel, M., Novák, P. \& Bruce, P. G. Rechargeable $\mathrm{Li}_{2} \mathrm{O}_{2}$ electrode for lithium batteries. J. Am. Chem. Soc. 128, 1390-1393 (2006).

5. Ottakam Thotiyl, M. M., Freunberger, S. A., Peng, Z. \& Bruce, P. G. The carbon electrode in nonaqueous $\mathrm{Li}_{-} \mathrm{O}_{2}$ cells. J. Am. Chem. Soc. 135, 494-500 (2012).

6. Lu, Y.-C et al. Platinum-gold nanoparticles: a highly active bifunctional electrocatalyst for rechargeable lithium-air batteries. J. Am. Chem. Soc. 132, 12170-12171 (2010).

7. Liu, S. et al. Direct growth of flower-like $\delta-\mathrm{MnO}_{2}$ on three-dimensional graphene for high-performance rechargeable $\mathrm{Li}-\mathrm{O}_{2}$ batteries. Adv. Energy Mater. 4, 1301960 (2014)

8. Thotiyl, M. M. O. et al. A stable cathode for the aprotic $\mathrm{Li}_{-} \mathrm{O}_{2}$ battery. Nat. Mater. 12, 1050-1056 (2013).

9. Li, F. et al. Superior performance of a $\mathrm{Li} \mathrm{P}_{2}$ battery with metallic $\mathrm{RuO}_{2}$ hollow spheres as the carbon-free cathode. Adv. Energy Mater. 5, 1500294 (2015).

10. Chen, Y., Freunberger, S. A., Peng, Z., Fontaine, O. \& Bruce, P. G. Charging a Li-O $\mathrm{O}_{2}$ battery using a redox mediator. Nat. Chem. 5, 489-494 (2013).

11. Bergner, B. J., Schürmann, A., Peppler, K., Garsuch, A. \& Janek, J. TEMPO: a mobile catalyst for rechargeable $\mathrm{Li}_{-} \mathrm{O}_{2}$ batteries. J. Am. Chem. Soc. 136, 15054-15064 (2014).

12. Lim, H. D. et al. Superior rechargeability and efficiency of lithium-oxygen batteries: hierarchical air electrode architecture combined with a soluble catalyst. Angew. Chem. Int. Ed. 53, 3926-3931 (2014)

13. Sun, D. et al. A solution-phase bifunctional catalyst for lithium-oxygen batteries. J. Am. Chem. Soc. 136, 8941-8946 (2014).

14. Feng, N., He, P. \& Zhou, H. Enabling catalytic oxidation of $\mathrm{Li}_{2} \mathrm{O}_{2}$ at the liquid-solid interface: the evolution of an aprotic $\mathrm{Li}-\mathrm{O}_{2}$ battery. ChemSusChem 8, 600-602 (2015)

15. Kwak, W.-J et al. Understanding the behavior of Li-oxygen cells containing LiI. J. Mater. Chem. A 3, 8855-8864 (2015).

16. Liu, T. et al. Cycling $\mathrm{Li}_{-} \mathrm{O}_{2}$ batteries via $\mathrm{LiOH}$ formation and decomposition. Science 350, 530-533 (2015).

17. Zhu, Y. G. et al. Dual redox catalysts for oxygen reduction and evolution reactions: towards a redox flow $\mathrm{Li}-\mathrm{O}_{2}$ battery. Chem. Commun. 51, 9451-9454 (2015).

18. Gao, X., Chen, Y., Johnson, L. \& Bruce, P. G. Promoting solution phase discharge in $\mathrm{Li}-\mathrm{O}_{2}$ batteries containing weakly solvating electrolyte solutions. Nat. Mater. 15, 882-888 (2016).

19. Zhu, Y. G., Wang, X., Jia, C., Yang, J. \& Wang, Q. Redox-mediated ORR and OER reactions: redox flow lithium oxygen batteries enabled with a pair of soluble redox catalysts. ACS Catal 6, 6191-6197 (2016).

20. Aetukuri, N. B. et al. Solvating additives drive solution-mediated electrochemistry and enhance toroid growth in non-aqueous $\mathrm{Li}-\mathrm{O}_{2}$ batteries Nat. Chem. 7, 50-56 (2015).

21. Schwenke, K. U., Metzger, M., Restle, T., Piana, M. \& Gasteiger, H. A. The influence of water and protons on $\mathrm{Li}_{2} \mathrm{O}_{2}$ crystal growth in aprotic $\mathrm{Li}-\mathrm{O}_{2}$ cells. J. Electrochem. Soc. 162, A573-A584 (2015).

22. Viswanathan, V. et al. Comment on 'Cycling $\mathrm{Li}^{-\mathrm{O}_{2}}$ batteries via $\mathrm{LiOH}$ formation and decomposition'. Science 352, 667-667 (2016).

23. Shen, Y., Zhang, W., Chou, S.-L \& Dou, S.-X. Comment on 'Cycling Li-O batteries via $\mathrm{LiOH}$ formation and decomposition'. Science 352, 667-667 (2016).

24. Liu, T. et al. Response to comment on 'Cycling $\mathrm{Li}^{-\mathrm{O}_{2}}$ batteries via $\mathrm{LiOH}$ formation and decomposition'. Science 352, 667-667 (2016).

25. Kwak, W.-J et al. $\mathrm{Li}-\mathrm{O}_{2}$ cells with $\mathrm{LiBr}$ as an electrolyte and a redox mediator. Energy Environ. Sci. 9, 2334-2345 (2016).

26. Burke, C. M. et al. Implications of 4 e-oxygen reduction via iodide redox mediation in $\mathrm{Li}_{-} \mathrm{O}_{2}$ batteries. ACS Energy Lett. 1, 747-756 (2016).

27. Zhang, W. et al. Promoting $\mathrm{Li}_{2} \mathrm{O}_{2}$ oxidation via solvent-assisted redox shuttle process for low overpotential $\mathrm{Li}_{2} \mathrm{O}_{2}$ battery. Nano Energy 30, 43-51 (2016).

28. Li, F. et al. The water catalysis at oxygen cathodes of lithium-oxygen cells. Nat. Commun. 6, 7843 (2015).

29. Wu, S. et al. A synergistic system for lithium-oxygen batteries in humid atmosphere integrating a composite cathode and a hydrophobic ionic liquid-based electrolyte. Adv. Funct. Mater. 26, 3291-3298 (2016).

30. Aurbach, D., McCloskey, B. D., Nazar, L. F. \& Bruce, P. G. Advances in understanding mechanisms underpinning lithium-air batteries. Nat. Energy 1, 16128 (2016).
31. Choban, A., Yurchuk, I. \& Lyavinets, A. Effect of base nature on the oxidation of dimethyl sulfoxide with hydrogen peroxide in superbasic media. Russ. J. Gen. Chem. 82, 247-250 (2012).

32. Black, R. et al. Screening for superoxide reactivity in $\mathrm{Li}-\mathrm{O}_{2}$ batteries: effect on $\mathrm{Li}_{2} \mathrm{O}_{2} / \mathrm{LiOH}$ crystallization. J. Am. Chem. Soc. 134, 2902-2905 (2012).

33. Cohen, A. J. Observations on several compounds of lithium and oxygen. $\mathrm{I}^{1 \mathrm{a}, 1 \mathrm{~b}}$ J. Am. Chem. Soc. 74, 3762-3764 (1952).

34. Vol'nov, I. \& Petrocelli, A. Peroxides, superoxides, and ozonides of alkali and alkaline earth metals (Springer, 1966).

35. Adams, S. Practical considerations in determining bond valence parameters (Springer, 2013).

36. Adams, S. \& Rao, R. P. Simulated defect and interface engineering for high power Li electrode materials. Solid State Ion. 184, 57-61 (2011).

37. Adams, S. \& Rao, R. P. High power lithium ion battery materials by computational design. Phys. Status Solidi (a) 208, 1746-1753 (2011).

38. Behl, W. K. \& Chin, D. T. Electrochemical overcharge protection of rechargeable lithium batteries i. kinetics of iodide/tri-iodide/iodine redox reactions on platinum in solutions. J. Electrochem. Soc. 135, 16-21 (1988).

39. Staszak-Jirkovský, J. et al. Water as a promoter and catalyst for dioxygen electrochemistry in aqueous and organic media. ACS Catal. 5, 6600-6607 (2015).

40. Matsui, M. et al. A novel aqueous lithium-oxygen cell based on the oxygen-peroxide redox couple. Chem. Commun. 51, 3189-3192 (2015).

41. Frisch, M. et al. Gaussian 09, revision A. 02 (Gaussian, Inc., 2009).

42. Becke, A. D. Density-functional thermochemistry. III. The role of exact exchange. J. Chem. Phys. 98, 5648-5652 (1993).

43. Sinha, P., Boesch, S. E., Gu, C., Wheeler, R. A. \& Wilson, A. K. Harmonic vibrational frequencies: scaling factors for HF, B3LYP, and MP2 methods in combination with correlation consistent basis sets. J. Phys. Chem. A 108, 9213-9217 (2004).

44. Hermansson, K. \& Thomas, J. O. The experimental electron density in lithium hydroxide monohydrate. Acta Crystallogr. B Struct. Crystallogr. Cryst. Chem. 38, 2555-2563 (1982).

\section{Acknowledgements}

This research was supported by the National Research Foundation, Prime Minister's Office, Singapore, under its Competitive Research Program (CRP Awards No NRF-CRP8-2011-04 and NRF-CRP10-2012-06). We thank Dr Du Yuan for his assistance on the FTIR measurement. We thank Professor Hui Ying Yang and Dr Linfeng Sun from Singapore University of Technology and Design for their assistance on Raman measurement.

\section{Author contributions}

Q.W. conceived the study and supervised the work. Y.G.Z. designed and performed most of the experiments. Q.L., Y. Rong and Y. Ren conducted synchrotron XRD measurements and data analysis. S.A. solved the crystal structure of $\mathrm{LiOOH} \cdot \mathrm{H}_{2} \mathrm{O}$. C.J. provided some scientific suggestion. X.X. prepared the LAGP membrane. J.Y., L.-J.Y A.K. and H.C. did the DFT calculations. Y.G.Z., S.A. and Q.W. wrote the paper.

\section{Additional information}

Supplementary Information accompanies this paper at http://www.nature.com/ naturecommunications

Competing financial interests: The authors declare no competing financial interests.

Reprints and permission information is available online at http://npg.nature.com/ reprintsandpermissions/

How to cite this article: Zhu, Y. G. et al. Proton enhanced dynamic battery chemistry for aprotic lithium-oxygen batteries. Nat. Commun. 8, 14308 doi: $10.1038 /$ ncomms14308 (2017)

Publisher's note: Springer Nature remains neutral with regard to jurisdictional claims in published maps and institutional affiliations.

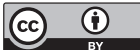

This work is licensed under a Creative Commons Attribution 4.0 International License. The images or other third party material in this article are included in the article's Creative Commons license, unless indicated otherwise in the credit line; if the material is not included under the Creative Commons license, users will need to obtain permission from the license holder to reproduce the material. To view a copy of this license, visit http://creativecommons.org/licenses/by/4.0/

(C) The Author(s) 2017 